\title{
Polymorphisms of Bovine Lymphocyte Antigen (BoLA DRB 3.2 Locus PstI) Gene in Bali Cattle Population from South Sulawesi Province
}

\author{
Ishak $\mathrm{ABL}^{1}$, Dagong MIA ${ }^{2}$, Nurul $\mathrm{P}^{3}$ \\ ${ }^{1}$ South Sulawesi Assesment Institute of Agriculture Technology \\ Jl. Perintis Kemerdekaan Km. 17, Makassar, South Sulawesi, Indonesia \\ ${ }^{2}$ Animal Production, Department Faculty of Animal Sciences, Hasanuddin University \\ Jl. Lasoso No. 64, Lolu, Biromaru, Palu, Central Sulawesi, Indonesia \\ ${ }^{3}$ Integrated Biotechnology Laboratory, Faculty of Animal Sciences, Hasanuddin University \\ Jl. Perintis Kemerdekaan Km. 10, Makassar, South Sulawesi, Indonesia \\ ihsandagong@gmail.com
}

\begin{abstract}
Immune Response in cattle is determined by polymorphism of major histocompatibility complex (MHC) gene mainly Bovine Lymphocyte Antigen. The aim of this study is to identify the genetic polymorphism of Bovine Lymphocyte Antigen (BoLA DRB.3) gene exon 2 as a marker for infectious disease resistance of Bali cattle in South Sulawesi, Indonesia. A total of 200 blood samples were extracted for DNA templated. It was amplified by using a PCR-RFLP method and digested with Pst1 restriction enzyme. Restriction of PCR product by Pst1 enzyme represented two digested fragments. The pp homozygous genotype showed two fragment 270 and 15 bp (not demonstrated). Pp heterozygous genotype showed four fragment 270, 226, 44 (not demonstrated), and $15 \mathrm{bp}$ (not demonstrated). Reffering from this result this research, the frequency of allele $\mathrm{P}$ $(0.925)$, allele $\mathrm{p}(0.075)$. The frequency genotype of PP $(0.850)$, frequency of genotype $\mathrm{Pp}(0.150)$, polymorphism information content $(0.129)$. Heterozygosity observed $(0.150)$ and heterosygosity expected (0.139).
\end{abstract}

Key Words: Bali Cattle, MHC BoLA Gene, PCR-RLFP

\section{INTRODUCTION}

Bali cattle is an indigeneous cattle in Indonesia (Mohamad et al. 2009; Martojo 2012; Purwantara 2012) and until very recently, there are no available information relate to genetic polymorphism Major Histocompatibility Complex (MHC) gene or BoLA DRB.3. The gene is important in marking disease resistance for cattle. MHC is clasified into three different classes, class I, II, and III.

The major histocompatibility complex (MHC) is a fundamental part of the immune system in nearly all vertebrates. It is one of the most important genetic systems for infectious disease resistance in vertebrates. There are three different groups of histocompatibility antigens, class I, II, and III. Class I molecules consist of an alpha chain with a molecular mass of about $45 \mathrm{KDa}$ (heavy chain) associated noncovalently with $\beta 2$ microglobulin chain which is around $12 \mathrm{Kda}$ and the molecules are expressed in all nucleated cells, and their main function is to present peptides to CD8+ T-lymphocytes, which kill virus-infected and neoplastic cells. The class II gene are distributed in two regions, II a and II b, with an approximate recombination frequency of $17 \%$ (Davies et al. 1997; Bastos-Silveira et al. 2008).

The DRA, DRB, DQA, and DQB genes are located in the II a region, while the DOB, DYA, DYB and DIB genes in the IIb region. There are at least three DRB-like genes (DRB1, DRB2, and DBR3) in the BoLA region, among which only the DRB3 gene is expressed considerably and is highly polymorphic (Andersen et al. 1988; Davies et al. 1997). The aim of this research was to observe polymorphism of BoLA DRB3 in Bali cattle which became a genetic marker in selection program. 


\section{MATERIAL AND METHODS}

\section{DNA extraction}

Blood samples (aproximately 2 to $4 \mathrm{ml}$ ) were obtained from jugularis vein of 200 heads Bali cattle, into a vacuntainer tube containing and stored in $10 \%$ of $0.5 \mathrm{M}$ EDTAcoated vacuntainer tubes (BD Vacuntainer Systems Plymuth. UK). The samples were collected from different villages and other region in South Sulawesi (develompment area of Bali cattle in Indonesia). Genomic DNA was isolated from blood plasma using DNA extraction kit (Qiagen, Germany) accordance to the protocol of the manufacture. The total DNA was measure at $260 \mathrm{~nm}$ optical density according to the methods described by Sambrook \& Russell (2001).

\section{Amplification of BoLA DRB3 exon 2}

The second exon of the BoLA DRB.3 gene was amplified by polymerase chain reaction (PCR). The isolated DNA was used for PCR amplification of the DRB.3 gene fragment of $285 \mathrm{bp}$. Primer specific for exon 2 BoLA DRB.3 were used to amplification for this region according Ripoli et al. (2004) and Miretti et al. (2001) (F: 5'GAGCCTCCAG AGAAATACAGGC-3'), R: (5'-TGTTTCAGAAAAGGACCTTC-3'). Reactions were carried out in a final volume of $25 \mu \mathrm{l}$. Each $\mu \mathrm{l}$ PCR reaction contained 100 $\mu \mathrm{LNA}, 0.2 \mathrm{pM}$ of each primer, $1 \times$ PCR buffer, $1.5 \mathrm{mM} \mathrm{MgCl}, 200 \mathrm{mM} \mathrm{dNTPs}$ and 1 unit Taq DNA polymerase (Fermentas, Germany). The PCR with primers was performed under the following conditions: initial denaturation at $95^{\circ} \mathrm{C}$ for 5 mins, followed by 30 cycles of denaturation at $94^{\circ} \mathrm{C}$ for $1 \mathrm{~min}$, annealing at $59^{\circ} \mathrm{C}$ for $1 \mathrm{~min}$ and elongation at $72^{\circ} \mathrm{C}$ for $1 \mathrm{~min}$.

\section{PCR-RFLP of BoLA DRB3 exon 2}

The PCR amplified products were digested separately with the restriction PstI (Fermentas, Germany). For restriction enzyme: $7 \mu$ of concentrated PCR products were digested at $37^{\circ} \mathrm{C}$ over night with three units of PstI. The digestion products were separated by horizontal electrophoresis ( 85 volts, 50 mins) in $2 \%$ agarose gels in $1 \times$ TBE and $10 \%$ ethidium bromide.

\section{Statistical analisys}

Data were analyzed by calculating allele and genotype frequencies (Nei \& Kumar 2000). The allele and genotype frequencies were calculated by the following formulas: $x_{i}=$ Allele frequencies; $\mathrm{n}_{i j}=$ Number of genotype $A_{i} A_{j} ; \mathrm{n}_{i i}=$ Total of genotype $A_{i} A_{i}$; $\mathrm{n}=$ Total sample; $\hat{\mathrm{h}}=$ heterozygosity.

Hardy-Weinberg equilibrium was tested by the $X^{2}$ (Chi-square) (Noor 2008) following formulas: where $\mathrm{X}^{2}=$ Hardy-Weinberg equilibrium test; $\mathrm{O}=$ Observed number of genotype; $\mathrm{E}=$ Expected number of genotype.

$$
x=\frac{\left(2 n_{i i}+\sum n_{i j}\right)}{2 n} \quad \hat{\mathrm{h}}=\frac{2 n\left(1-\sum x_{i}^{2}\right)}{2 n-1} \quad \mathrm{x}^{2}=\sum \frac{(0+E)^{2}}{E}
$$




\section{RESULTS AND DISCUSSION}

\section{Amplification and genotyping of BoLA DRB3 exon 2}

The amplicon BoLA DRB3 exon 2 was 284 bp (a lenght expected size as shown in Figure 1). This length was consistent with Ripoli et al. (2004) and Ruzina et al. (2010).

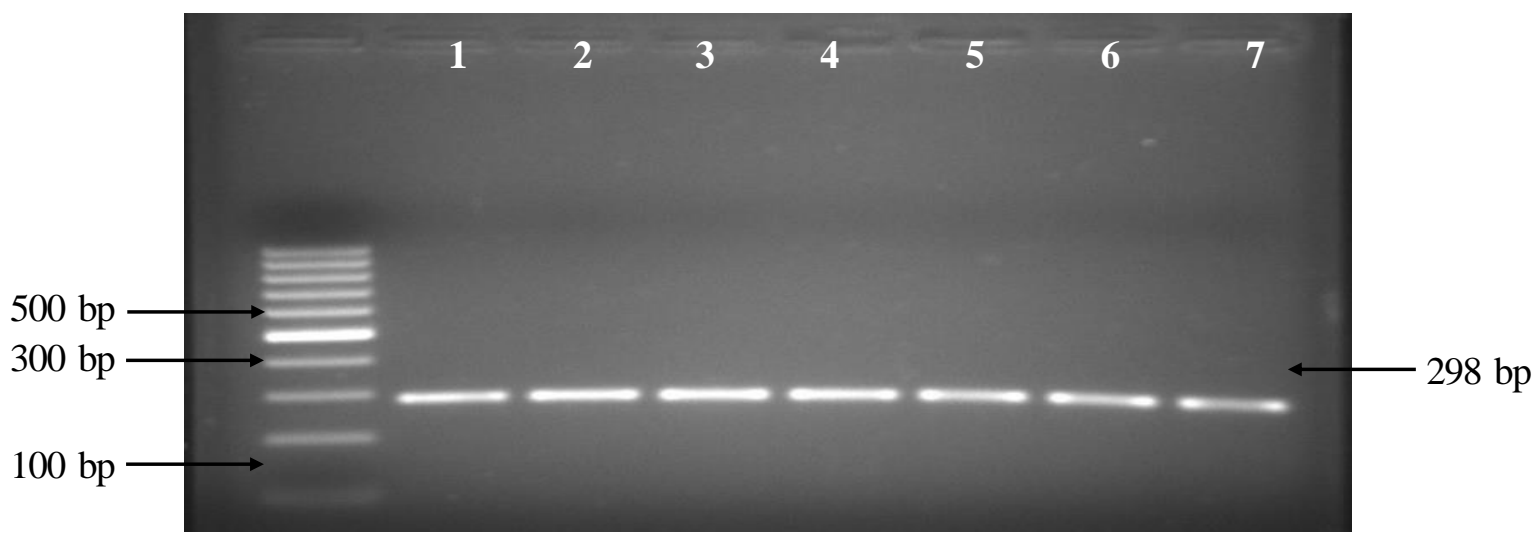

M: DNA marker ladder 100 bp; Lane 1-7: Samples

Figure 1. Amplification of BoLA DRB.3 gene exon 2 region

An important role in the immune system of cattle is decided by a close relationship with level of resistance to diseases. Referring from previous research, it is determined by MHC gene or Bovine Lymphocyte Antigene (BoLA) which found on the short arm bovine chromosomes 23 (BTA 23).

Bovine Lymphocyte Antigene has became a candidated gene and a major topic for researchers to observe due to two several reasons: (1) The function of this gene in controlling the immune response of the organisme to viral and bacterial infections; and (2) A high level polymorphism.

As can be seen from Figure. 2, it was found that only two different alleles in Bali cattle, allele $\mathrm{P}$ and $\mathrm{p}$, in Pst 1 restriction. Meanwhile, a research conducted by Ningtiyas et al. (2014) found five different alleles (A, B, C, E, and F) by using restriction enzyme HaeIII at the same fragment (exon 2).

In Bali cattle, using BoLA as a marker gene is very important in selection due to Bali cattle very susceptible to infection Jembrana disease and anthrax. Both diseases become a primary disease in Bali cattle.

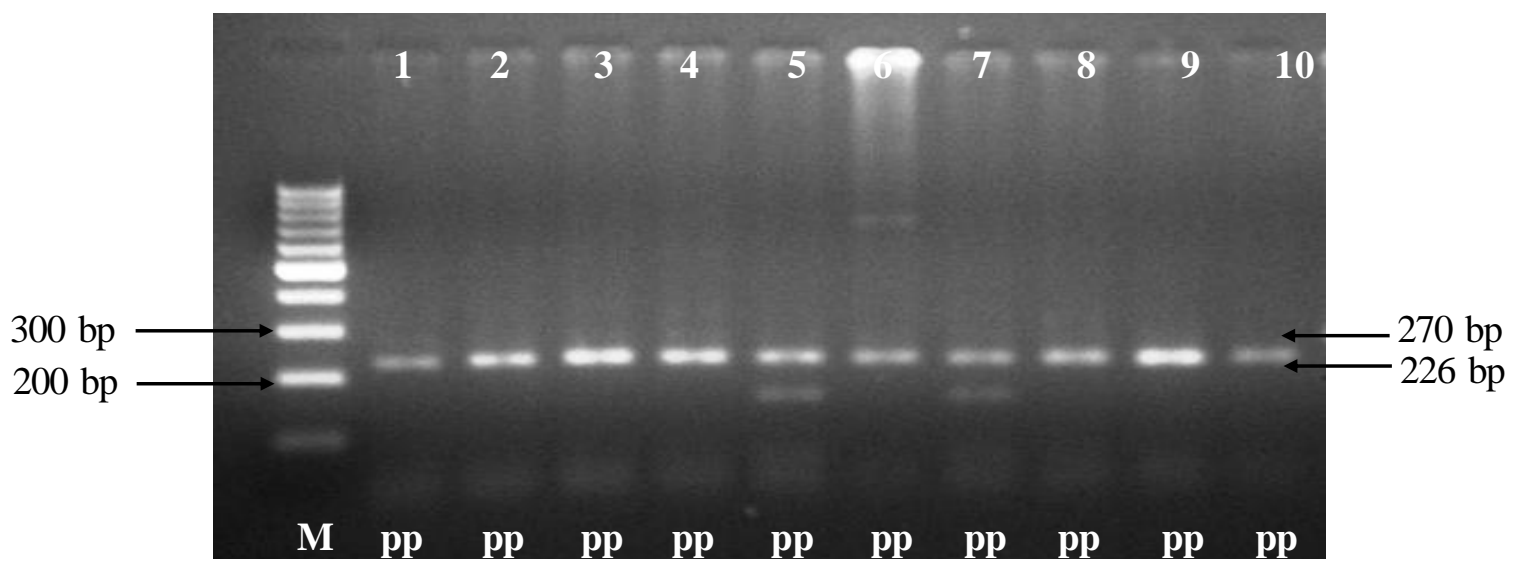

Figure 2. Genotypic of BoLA DRB.3 gene exon 2 region 
The PstI polymorphism site expressed at bands 226-, 44-, and 15- bp (P restriction pattern) and 270-, 15 bp (p restriction pattern). Lane $\mathrm{M}=100 \mathrm{bp}$ ladder marker, lane 1, 2, $3,4,8,9$, and 10 as the pp homozygous genotype showed two fragment 270 and 15 bp (not demonstrated), lane 5 and 7 as the Pp heterozygous genotype showed four fragment 270, 226, 44 bp (not demonstrated), and 15 bp (not demonstrated).

The result showed frequency of allele $\mathrm{P}(0.925)$ and allele $\mathrm{p}(0.075)$, frequency of genotype PP (0.850) and frequency of genotype Pp (0.150) and pp (0.000). It can be assumed that a low level of genotype and frequency in Bali cattle is caused by its breed has not been crossed to other. Similarly, Wu et al. (2010) also found a low level of frequency allele and genotype in Argentinian Creole.

Puja et al. (2011) observed Bali cattle and they found a different amount of alleles, seven alleles in Bali province while nine different alleles in Nusa Penida Island. Interestingly, the amount of different alleles in Puja's research is higher compared to the result of this research.

Referring from Table 1, heterozigosity of BoLA DRB3 exon 2 gene (Ho) was 0.150 and 0.139 of He. This amount was small compared to Ningtiyas et al. (2014) which found the amount of $0.755\left(\mathrm{H}_{\mathrm{o}}\right)$ and $0.644\left(\mathrm{H}_{\mathrm{e}}\right)$. It is indicated that Heterozigosity of BoLA DRB3 exon 2 gene is highest in locus HaeIII compared to locus Pst1.

Table 1. Genotype and allele frequency BoLA DRB3 exon 2 gene

\begin{tabular}{|c|c|c|c|c|c|c|c|c|c|}
\hline \multirow{2}{*}{ Population } & \multicolumn{2}{|c|}{ Freq. of allele } & \multicolumn{3}{|c|}{ Freq. of Genotype } & \multicolumn{2}{|c|}{ Heterozigosity } & \multirow{2}{*}{$X^{2}$} & \multirow{2}{*}{ PIC } \\
\hline & $\mathrm{P}$ & $\mathrm{p}$ & $\mathrm{PP}$ & $\mathrm{Pp}$ & $\mathrm{Pp}$ & Ho & $\mathrm{He}$ & & \\
\hline Bali & 0.925 & 0.075 & 0.850 & 0.150 & 0.000 & 0.150 & 0.139 & 0.526 & 0.129 \\
\hline
\end{tabular}

$\mathrm{X}^{2}$ : Chi-square; $\mathrm{H}_{\mathrm{o}}$ : Observed heterozygosity; $\mathrm{H}_{\mathrm{e}}$ Expected heterozygosity; PIC: Polymorphism information content

\section{CONCLUSION}

BoLA DRB. 3 exon 2 gene in Bali cattle is polymorphic and it can become a marker assisted selection to immune response and disease resistance.

\section{ACKNOWLEDGMENT}

The authors gratefully acknowledge for head of Agency Agriculture Research and Development, Ministry of Agriculture Indonesia. We also thank to all Bali cattle farmers in Bone and Barru Regency, South Sulawesi Province.

\section{REFERENCES}

Andersson L, Lundén A, Sigurdardóttir S, Davies CJ, Rask L. 1988. Linkage relationships in the bovine MHC region. High recombination frequency between class II subregions. Immunogenetics. 27:273-280.

Bastos-Silveira C, Luís C, Ginja C, Gama LT, Oom MM. 2008. Genetic variation in BoLA microsatellite loci in Portuguese cattle breeds. Anim Genet. 40:101-105.

Davies CJ, Andersson L, Ellis SA, Hensen EJ, Lewin HA, Mikko S, Muggli-Cockett NE, Van der Poel JJ, Russell GC. 1997. Nomenclature for factors of the BoLA system, 1996: Report of the ISAG BoLA nomenclature committee. Anim Genet. 28:159-168. 
Martojo H. 2012. Indigenous Bali cattle is most suitable for sustainable small farming in Indonesia. Reprod Dom Anim. 47:10-14.

Miretti MM, Ferro JA, Lara MA, Contel EPB. 2001. Restriction fragment length polymorphism (RFLP) in exon 2 of the BoLA-DRB3 gene in South American cattle. Biochem Genet. 39:311-324.

Mohammad K, Olsson M, Helena TA, Mikko S, Vlamings BH, Andersson G, Martmez HR, Purwantara B, Paling RW, Colenbrander B, Lenstra JA. 2009. On the origin of Indonesian cattle. PlosOne. 4:1-6.

Nei M, Kumar S. 2000. Molecular evolution and phylogenetics. New York (US): Oxford University Press.

Ningtiyas WD, Dagong MIA, Rahim L, Bugiwaty SRA, Ishak ABL. 2014. Allelic variation of MHC DRB3 gene in Bali and crossbred cattle from South Sulawesi, Indonesia. In: Subandriyo, Kusmartono, Santosa KA, Kurnianto E, Purnomoadi A, Sodiq A, Wiryawan KG, Darodjah S, Inounu I, Darmono, Priyanti A, Wynn P, han JL, Tay-Hsu J, Idrus Z, editors. Sustainable Livestock Production in the Perspective of Food Security, Policy, Genetic Resources, and Climate Cange. Proceedings of the $16^{\text {th }}$ AAAP Animal Science Congress Vol. II. Yogyakarta, 10-14 November 2014. Yogyakarta (Indonesia): Ministry of Agriculture, Indonesian Society of Animal Sciences, Gadjah Mada University. p. 97-100

Noor RR, 2008. Genetika ternak. $4^{\text {th }}$ Ed. Bogor (Indonesia): Penebar Swadaya.

Purwantara B, Noor RR, G Andersson G, Martinez HR. 2012. Banteng and Bali cattle in Indonesia: Status and forecasts. Reprod Dom Anim. 47:2-6.

Puja IK, Wandia IN, Suastika P, Sulabda IN. 2011. Polimorfisme genetik DNA mikrosatellite GEN BoLA lokus DRB3 pada sapi Bali (Bos indicus). Biota. 16:336-341.

Ripoli MV, Lir JP, De Luca JC, Rojas F, Dulout FN, Giovambattista G. 2004. Gene frequency distribution of the BoLA-DRB3 locus in Saavedreno Creole dairy cattle. Biochem Genet. 42:231-240.

Ruzina MN, Shtyfurkoa TA, Mohammadabadi MR, Gendzhievac OB, Tsedevd T. 2010. Polymorphism of the BoLA DRB3 gene in the Mongolian, Kalmyk, and Yakut cattle breeds. Russ J Genet. 46:456-463.

Wu XX, Yang ZP, Wang XL, Mao YJ, Li SC, Shi XK, Chen Y. 2010. Restriction fragment length polymorphism in the exon 2 of the BoLA-DRB3 gene in Chinese Holstein of the South China. J Biomed Sci Eng. 3:221-225

Sambrook J, Russell DW. 2001. Molecular cloning: A laboratory manual. $3^{\text {rd }}$ Ed. New York (US): Cold Spring Harbor Laboratory Press. 